\title{
How common is cholesterol embolism?
}

\author{
S S Cross
}

\begin{abstract}
Histological sections of spleen and both kidneys from 372 necropsies were examined for the presence of cholesterol emboli. These were identified in nine $(2 \cdot 4 \%)$ cases and the clinical histories of these cases were reviewed. All the subjects with cholesterol emboli were older than 60 years and eight out of nine were male. Lesions of differing ages were found in individual cases, suggesting that the process of embolism was recurrent. Two of the cases had undergone arteriography procedures in the month before death and, if these were excluded, then the incidence of "spontaneous" cholesterol embolism was $1.9 \%$. This incidence is much lower than that of previously published studies and may be due to a lower incidence of cholesterol embolism in Britain compared with North America or a decrease in incidence over the past two decades. In three of the subjects with cholesterol embolism the cause of death could be related to systemic atherosclerosis, but in the other six cases there was no apparent correlation between the finding of cholesterol embolism and the cause of death. The clinical relevance of the histological finding of cholesterol embolism can only be assessed in conjunction with clinical information.
\end{abstract}

Embolisation of cholesterol crystals from ulcerated atherosclerotic plaques is well known. Disseminated cholesterol emboli may produce a systemic illness ${ }^{12}$ with livedo reticularis of the lower limbs ${ }^{34}$ and splinter haemorrhages of the nails ${ }^{5}$; the features may mimic polyarteritis nodosa. ${ }^{67}$ Cholesterol embolism has also been documented as a cause of renal failure, ${ }^{89}$ acute pancreatitis, ${ }^{10-12}$ gastrointestinal haemorrhage, ${ }^{1314}$ bowel stricture ${ }^{1516}$ and spinal cord infarction. ${ }^{17}$ It can occur spontaneously but is also seen as a complication of aortic surgery, ${ }^{18}$ balloon angioplasty, ${ }^{19}$ and various angiographic procedures, ${ }^{20-22}$ including aortography, ${ }^{23}$ left heart catheterisation, ${ }^{24-26}$ renal arteriography ${ }^{27}$ and mesenteric angiography. ${ }^{28}$ Some reports have suggested that embolisation may be facilitated by thrombolytic treatment ${ }^{2930}$ which may prevent thrombus forming over ulcerated plaques; discontinuation of treatment may reverse the symptoms. ${ }^{31}$

Panum published one of the first descriptions of the pathology of cholesterol embolism in $1862^{32}$ and since then there have been several more comprehensive reports, ${ }^{33-43}$ but few of these studies examine the prevalence of cholesterol embolism. Flory examined histological sections from 267 necropsies and found that $3.4 \%$ of the cases had cholesterol emboli ${ }^{33}$; all these cases had been selected because the necropsy had shown "advanced arteriosclerosis" in the aorta. Other series with selected cases coming to necropsy include one restricted to subjects older than 60 years ${ }^{37}$ and another on subjects who had had arteriographic procedures. ${ }^{42}$ Maurizi et al looked at 100 consecutive necropsies and found that four contained cholesterol emboli in the lower extremities, ${ }^{40}$ but this is a North American study and was performed 23 years ago so it may not be relevant to a British population today.

Some estimate of the prevalence of cholesterol embolism is useful in the interpretation of biopsy specimens: a single cholesterol embolus in a vessel of a renal biopsy specimen would be of little relevance if such embolism was common, but if cholesterol embolism was rare then it would have to be regarded as a possible cause of the renal dysfunction. Preston et al reported 14 cases of cholesterol emboli in a series of 334 renal biopsy specimens from patients older than 65 years, ${ }^{44}$ but all these patients had renal failure before biopsy. Disseminated cholesterol embolism has been recognised as the cause of disease after identification in biopsy material ${ }^{4546}$ but these patients had clinical features, such as livedo reticularis, which provided confirmatory evidence. This study aimed to examine a large, apparently unbiased, sample of histological specimens taken at necropsy to produce an estimate of the current prevalence of cholesterol embolism in Britain.

\section{Methods}

The histological material from all necropsies performed at the Royal Hallamshire Hospital between 1987 and 1990 was reviewed. Cases with a slide of the spleen and each kidney were used in the study. The haematoxylin and eosin stained slides of these organs were screened at a final magnification of $\times 100$ for the presence of cholesterol emboli using the histological features described by Kennedy ${ }^{43}$ as criteria for identification. In cases where cholesterol emboli were found the slides were reexamined, the number of lesions was recorded, and assessment of lesional age was made using the features described by Flory ${ }^{33}$ and Snyder and Shapiro. ${ }^{39}$ The external diameter of all vessels containing cholesterol emboli was measured. The clinical history of all positive cases was reviewed, together with the cause of death stated after necropsy.

The age and sex of all subjects coming to 


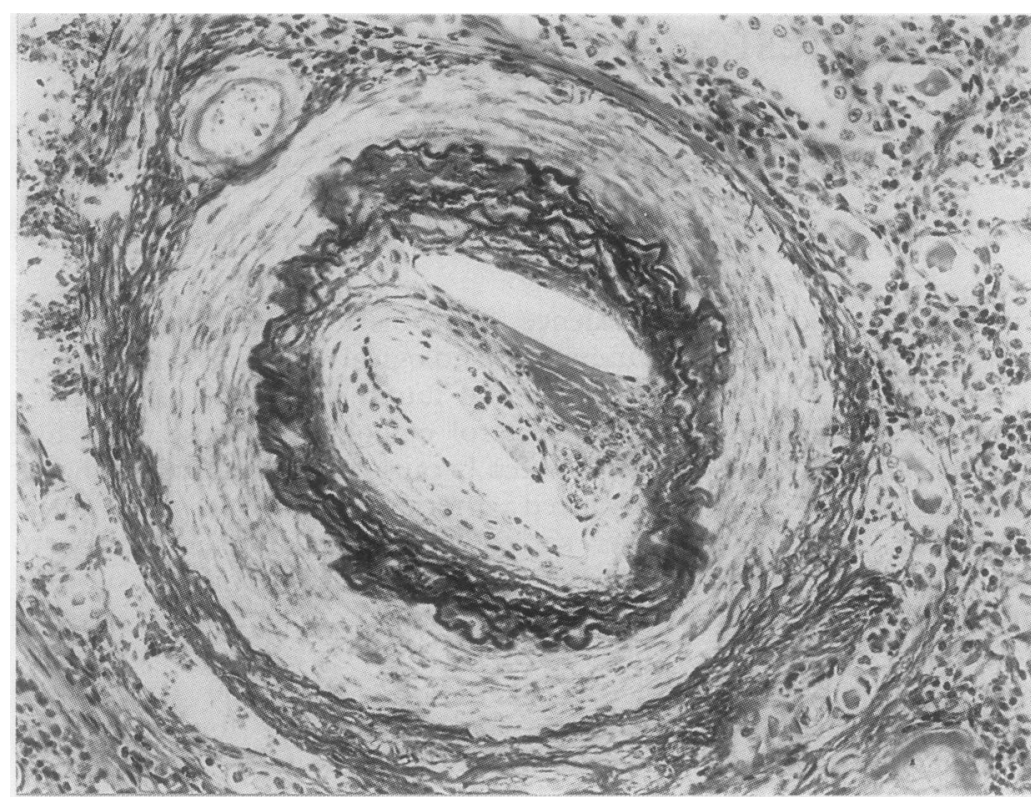

Fibrous tissue surrounding two cholesterol-crystal-shaped clefts in the lumen of an artery in the kidney (elastic van Gieson).

necropsy was recorded. The age distribution of the total necropsy population was compared with those necropsies with histology using the Mann-Whitney U test; the sex distribution of these two groups was examined using the $\chi^{2}$ test.

\section{Results}

Necropsies $(n=1838)$ were performed during the study period on 1038 men $(56 \%)$ and 800 women $(44 \%)$ with a mean age of 66.5 years (range 10-99 years). Three hundred and seventy-two of these necropsies had slides of the spleen and both kidneys; 212 (57\%) were from men and $160(43 \%)$ from women with a mean age of 66.4 years (range 17-92 years). Cholesterol emboli (figure) were identified in nine cases $(2 \cdot 4 \%$ of those cases with appropriate histological material). The age distributions of these populations are given in table 1. There was no significant difference
Table 3 Number of lesions of different ages

\begin{tabular}{llll}
\hline Case No & $\begin{array}{l}\text { Recent } \\
\text { lesions } \\
(<3 \text { days) }\end{array}$ & $\begin{array}{l}\text { Giant cell } \\
\text { lesions } \\
\text { (3-6 days) }\end{array}$ & $\begin{array}{l}\text { Fibrotic } \\
\text { lesions } \\
(>6 \text { days) }\end{array}$ \\
\hline 1 & 4 & 0 & 2 \\
2 & 1 & 1 & 1 \\
3 & 0 & 0 & 1 \\
4 & 0 & 0 & 4 \\
5 & 2 & 0 & 0 \\
6 & 0 & 0 & 4 \\
7 & 0 & 0 & 3 \\
8 & 5 & 0 & 6 \\
9 & 1 & 0 & 0 \\
Total & 13 & 1 & 21 \\
\hline
\end{tabular}

( $p>0.5$ ) between the age or sex distributions in the group of necropsies with appropriate histology compared with all the necropsies. Tables 2 and 3 summarise the results in the positive cases. The median external diameter of vessels containing cholesterol emboli was 166 $\mu \mathrm{m}$ (range 71-536 $\mu \mathrm{m}$ ). The two cases with antemortem angiography had each had left heart catheterisations four weeks before death.

\section{Discussion}

This is a retrospective study and so there are potential problems with bias in the sample of necropsies which had appropriate histology available. The selection of histological material was made by individual pathologists with no agreed sampling protocol, so it is possible that the cases with two slides of kidneys and one of spleen differed from the overall population of necropsies, but there was no significant difference in the age or sex distribution of the two populations. The causes of death in the two groups could not be compared as no suitable analytical framework could be devised.

Much of the data from this study confirm the features of cholesterol embolism reported previously. ${ }^{33-41}$ Most (8/9) of subjects were male and all were older than 60 . Lesions of differing ages were found in individual cases, suggesting that the process of embolism was recurrent. It was not possible to grade the degree of aortic atheroma from the subjective evaluation available in the necropsy reports, but most descriptions included the presence of

Table 1 Age distribution of study populations

\begin{tabular}{|c|c|c|c|c|c|c|c|c|}
\hline \multirow[b]{2}{*}{ Population } & \multicolumn{8}{|c|}{ Number of cases in age division (years) } \\
\hline & $10-19$ & $20-29$ & $30-39$ & $40-49$ & $50-59$ & $60-69$ & $70-79$ & $80-89$ \\
\hline $\begin{array}{l}\text { All necropsies } \\
\text { With renal and splenic histology } \\
\text { With emboli }\end{array}$ & $\begin{array}{r}29 \\
4 \\
0\end{array}$ & $\begin{array}{r}56 \\
9 \\
0\end{array}$ & $\begin{array}{r}54 \\
12 \\
0\end{array}$ & $\begin{array}{r}107 \\
26 \\
0\end{array}$ & $\begin{array}{r}224 \\
50 \\
0\end{array}$ & $\begin{array}{r}457 \\
87 \\
3\end{array}$ & $\begin{array}{r}533 \\
115 \\
5\end{array}$ & $\begin{array}{r}333 \\
61 \\
1\end{array}$ \\
\hline
\end{tabular}

Table 2 Details of cases with cholesterol emboli

\begin{tabular}{|c|c|c|c|c|c|c|c|}
\hline \multirow[b]{2}{*}{ Case No } & \multirow[b]{2}{*}{ Age (years) } & \multirow[b]{2}{*}{ Sex } & \multicolumn{2}{|c|}{ Number of emboli } & \multirow[b]{2}{*}{ Angiography? } & \multirow{2}{*}{$\begin{array}{l}\text { Thrombolytic } \\
\text { treatment }\end{array}$} & \multirow[b]{2}{*}{ Cause of death } \\
\hline & & & Kidneys & Spleen & & & \\
\hline $\begin{array}{l}1 \\
2 \\
3 \\
4 \\
5 \\
6 \\
7 \\
8 \\
9\end{array}$ & $\begin{array}{l}62 \\
66 \\
67 \\
70 \\
71 \\
73 \\
77 \\
79 \\
81\end{array}$ & $\begin{array}{l}M \\
M \\
M \\
M \\
M \\
M \\
M \\
M \\
F\end{array}$ & $\begin{array}{l}5 \\
0 \\
1 \\
1 \\
1 \\
1 \\
0 \\
8 \\
1\end{array}$ & $\begin{array}{l}1 \\
3 \\
0 \\
3 \\
1 \\
3 \\
3 \\
3 \\
0\end{array}$ & $\begin{array}{l}\mathbf{N} \\
\mathbf{Y} \\
\mathbf{Y} \\
\mathbf{N} \\
\mathbf{N} \\
\mathbf{N} \\
\mathbf{N} \\
\mathbf{N} \\
\mathbf{N}\end{array}$ & $\begin{array}{l}\mathbf{N} \\
\mathbf{N} \\
\mathbf{N} \\
\mathbf{N} \\
\mathbf{N} \\
\mathbf{N} \\
\mathbf{N} \\
\mathbf{N} \\
\mathbf{N}\end{array}$ & $\begin{array}{l}\text { Carcinoma of bladder } \\
\text { Myocardial infarction } \\
\text { Myocardial infarction } \\
\text { Carcinoma of bronchus } \\
\text { Myocardial infarction } \\
\text { Pulmonary embolism } \\
\text { Subarachnoid haemorrhage } \\
\text { Obstructive uropathy } \\
\text { Multiple injuries }\end{array}$ \\
\hline
\end{tabular}


extensive ulcerated atherosclerotic plaques.

The overall prevalence of cholesterol embolism in the kidneys and spleen in this study $(2.4 \%)$ is lower than that found in the study by Maurizi (4\%). ${ }^{40}$ That study included biopsy specimens of the lower extremities which could have increased the number of cases detected, but 24 of the 25 cases had cholesterol emboli in the kidneys, 15 had emboli in the spleen, and all cases had emboli in either the kidneys or spleen. The prevalence in subjects 60 years and older in this study $(3.4 \%)$ is much lower than the $17 \cdot 6 \%$ reported by Gore ${ }^{37}$ a North American series performed 30 years ago. In Gore's study 12 of the 13 cases had emboli in the kidneys and 10 had emboli in the spleen. Two of the positive cases in this study had had left heart catheterisation four weeks before death, this is well recognised inciting factor for cholesterol embolism. ${ }^{24-26}$ If these cases are excluded then the prevalence of "spontaneous" cholesterol embolism in this study is $1.9 \%$, which is lower than that of previous studies, and may indicate a lower prevalence of cholesterol embolism in Britain compared with North America or a decrease in prevalence over the past two decades. This low prevalence might suggest that cholesterol embolism in biopsy material is a clinically important finding, but the causes of death in this study do not support this. Three of the subjects died with myocardial infarction, and the cholesterol embolism could be regarded as a marker of severe atherosclerosis; the other deaths were from a variety of causes with no apparent relation with cholesterol embolism.

The main conclusion of this study is that cholesterol embolism is rare, even in selected populations such as subjects older than 60 , but its clinical importance can be assessed only in conjunction with other clinical information.

1 Eliot RS, Kanjuh VI, Edwards JE. Atheromatous embolism. Circulation 1964;30:611-8.

2 Rosman HS, Davis TP, Reddy D, Goldstein S. Cholesterol embolization: clinical findings and implications. J Am Coll Cardiol 1990;15:1296-9.

3 Fisher ER, Hellstrom R, Myers JD. Disseminated atheromatous emboli. Am J Med 1960;29:176-80.

4 Scully RE, McNeely BU. Case records of the Massachusetts General Hospital. $N$ Engl J Med 1974;291:406-12.

5 Turakhia AK, Khan MA. Splinter haemorrhages as a possible clinical manifestation of cholesterol crystal embolization. J Rheumatol 1990;17:1083-6.

6 Anderson WR. Necrotizing angitis associated with embolization of cholesterol: case report with emphasis on the use of the muscle biopsy as a diagnostic aid. Am J Clin the use of the muscle

7 Richards AM, Eliot RS, Kanjuh VI, Bloemendaal RD, Edwards JE. Cholesterol embolism: a multiple-system disease masquerading as polyarteritis nodosa. Am J Cardiol 1965;15:696-707.

8 Meyrier A, Buchet P, Simon P, Fernet M, Rainfray M Callard P. Atheromatous renal disease. Am J Med 1988; 85:139-46.

9 Smith MC, Ghore MK, Henry AR. The clinical spectrum of renal cholesterol embolization. Am J Med 1981;71:174-80

10 Probstein JG, Joshi RA, Blumethal HT. Atheromatous embolization: an etiology of acute pancreatitis. Arch Surg 1957;75:566-72.

11 Moldveen-Geronimus M, Merriam JC. Cholesterol embolization-from pathological curiosity to clinical embolization-from pathological

12 Castleman B, McNeely BU. Case records of the Massachusetts General Hospital. N Engl J Med 1967;276:
13 Forouhar FA, Mohit M, Gardner P, Smith N. Cholesterol embolism causing bleeding gastric ulcers. Ann Clin Lab Sci 1988;18:260-5.

14 Francis J, Kapoor WN. Intestinal pseudopolyps and gastrointestinal haemorrhage due to cholesterol crystal embolization. Am JMed 1988;85:269-71.

15 Blundell JW. Small bowel stricture secondary to multiple cholesterol emboli. Histopathology 1988;13:459-62.

16 Chan T, Levine MS, Park Y. Cholesterol embolization as a cause of cecal infarct mimicking carcinoma. Am J Radiol 1988; 150:1315-6.

17 Harrington D, Amplatz K. Cholesterol embolization and spinal infarction following aortic catheterization. $\mathrm{Am} \mathrm{J}$ Radiol 1972; 115:171-9.

18 Thurlbeck WM, Castleman B. Atheromatous emboli to the kidneys after aortic surgery. $N$ Engl J Med 1957;257: 442-7.

19 Belli AM, Cumberland DC, Knox AM, Procter AE, Welsh CL. The complication rate of peripheral balloon angiopL. The complication rate of perip

20 Rosansky SJ, Deschamps EG. Multiple cholesterol emboli syndrome after angiography. Am J Med Sci 1984;288. 45-8.

21 Gaines PA, Cumberland DC, Kennedy A, Welsh CL Moorhead P, Rutley MS. Cholesterol embolism: a letha complication of vascular catheterisation. Lancet 1988; 168-70

22 Palmer FJ, Warren BA. Multiple cholesterol emboli syndrome complicating angiographic techniques. Clin Radiol 1988;39:519-22.

23 Lonni YGW, Matsumoto KK, Lecky JW. Postaortographic cholesterol (atheromatous) embolization. Radiology 1968;93:63-5.

24 Gjesdal K, Orning OM, Smith E. Fatal atheromatous emboli to the kidneys after left-heart catheterization. Lancet 1977;ii:405.

25 Drost H, Buis B, Haan D, Hillers JA. Cholesterol embolism as a complication of left heart catheterization: report of seven cases. Br Heart J 1984;52:339-42.

26 Freund NS. Cholesterol emboli syndrome following cardiac catheterization. Postgrad Med J 1990;87:55-60.

27 Harrington JT, Sommers SC, Kassiner JP. Atheromatous emboli with progressive renal failure: renal arteriography as the probable inciting factor. Ann Int Med 1968;68: $152-60$.

28 Henderson MJ, Manhire AR. Cholesterol embolization following angiography. Clin Radiol 1990;42:281-2

29 Pirson Y, Honhon B, Cosyns JP, van Ypersele C. Cholesterol embolism in a renal graft after treatment with streptokinase. Br Med J 1988;296:394-5.

30 Queen M, Biem HJ, Moe GW, Sugar L. Development of cholesterol embolization after intravenous streptokinase for acute myocardial infarction. Am J Cardiol 1990;65 1042-3

31 Kawakami Y, Hirose K, Watanabe Y et al. Management of multiple cholesterol embolization syndrome-a case report. Angiology 1990;41:248-52.

32 Panum PL. Experimentelle beitrage zur lehre von der embolie. Virchows Arch (Pathol Anat) 1862;25:308-38.

33 Flory CM. Arterial occlusions produced by emboli from eroded aortic atheromatous plaques. Am J Pathol 1945;21:549-65.

34 Meyer WW. Cholesterin krystallembolie leinen organarterien und ihre folgen. Virchows Arch (Pathol Anat) 1947;314:616-38.

35 Zak FG, Elias K. Embolization with material from atheromata. Am J Med Sci 1949;218:510-5.

36 Handler FP. Clinical and pathologic significance of ath eromatous embolization, with emphasis on an etiology of renal hypertension. Am J Med 1956;20:366-73.

37 Gore I, Collins DP. Spontaneous atheromatous embolization: review of the literature and a report of 16 additional cases. Am J Clin Pathol 1960;33:416-26.

38 Schnornagel HE. Emboli of cholesterol crystals. J Pathol Bacteriol 1961;81:119-22.

39 Snyder HE, Shapiro JL. A correlative study of atheromatous embolism in human beings and experimental animals. Surgery 1961;49:195-204.

40 Maurizi CP, Barker AE, Trueheart RE. Atheromatous emboli: a postmortem study with special reference to the lower extremities. Arch Pathol 1968;86:528-34.

41 Perdue GD, Smith RB. Atheromatous microemboli. Arch Pathol 1968;86:954-9.

42 Ramirez G, O'Neill WM, Lambert R, Bloomer HA. Cholesterol embolization: a complication of angiography. Arch Intern Med 1978;138:1430-2.

43 Kennedy A, Cumberland D, Gaines P. The pathology of cholesterol embolism arising as a complication of intraaortic catheterization. Histopathology 1989;15:515-21.

44 Preston RA, Stemmer CL, Materson BJ, Perez-Stable E Pardo V. Renal biopsy in patients 65 years of age or older: an analysis of the results of 334 biopsies. J Am Geriatr Soc an analysis of the

45 Retan JW, Miller RE. Microembolic complications of atherosclerosis: literature review and report of a patient. Arch Intern Med 1966;118:534-45.

46 Anderson WR, Richards AM. Evaluation of lower extremity muscle biopsies in the diagnosis of atheroembolism. Arch Pathol 1968;86:535-41. 